\title{
Effects of rAAV-Mediated sox9 Overexpression on the Biological Activities of Human Osteoarthritic Articular Chondrocytes in Their Intrinsic Three-Dimensional Environment
}

\author{
Oliver Daniels, Janina Frisch, Jagadeesh K. Venkatesan, Ana Rey-Rico $₫$, Gertrud Schmitt and \\ Magali Cucchiarini *D \\ Center of Experimental Orthopaedics, Saarland University Medical Center and Saarland University, \\ Kirrbergerstr. Bldg. 37, D-66421 Homburg/Saar, Germany; mueller.oliver90@gmx.de (O.D.); \\ janina.frisch@gmx.de (J.F.); jegadish.venki@gmail.com (J.K.V.); ana.rey.rico@gmail.com (A.R.-R.); \\ gertrud.schmitt@uniklinikum-saarland.de (G.S.) \\ * Correspondence: mmcucchiarini@hotmail.com; Tel.: +49-6841162-4987; Fax: +49-6841162-4988
}

Received: 26 August 2019; Accepted: 2 October 2019; Published: 7 October 2019

\begin{abstract}
Gene therapy for osteoarthritis offers powerful, long-lasting tools that are well adapted to treat such a slow, progressive disorder, especially those therapies based on the clinically adapted recombinant adeno-associated viral (rAAV) vectors. Here, we examined the ability of an rAAV construct carrying a therapeutic sequence for the cartilage-specific SOX9 transcription factor to modulate the phenotype of human osteoarthritic articular chondrocytes compared with normal chondrocytes in a three-dimensional environment where the cells are embedded in their extracellular matrix. Successful sox 9 overexpression via rAAV was noted for at least 21 days, leading to the significant production of major matrix components (proteoglycans, type-II collagen) without affecting the proliferation of the cells, while the cells contained premature hypertrophic processes relative to control conditions (reporter rAAV-lacZ application, absence of vector treatment). These findings show the value of using rAAV to adjust the osteoarthritic phenotype when the chondrocytes are confined in their inherently altered environment and the possibility of impacting key cellular processes via gene therapy to remodel human osteoarthritic cartilage lesions.
\end{abstract}

Keywords: cartilage repair; osteoarthritis; rAAV; SOX9; chondrocyte phenotype

\section{Introduction}

Osteoarthritis (OA) is a progressive whole joint disorder mostly characterized by an irreversible destruction of the articular cartilage; it is also associated with pathological bone and synovial changes (inflammation, remodeling, osteophyte formation) [1-3] resulting from an impeded homeostasis in all tissues, with a disruption of the balance between anabolism and catabolism in the chondrocytes (the unique cells forming the cartilage) that undergo phenotypic alterations (suppression of the expression of genes coding for matrix-specific COL2A1, expression of hypertrophic genes such as COL10A1) $[4,5]$. Despite the availability of a number of pharmacological and surgical regimens $[6,7]$, including cell-based and biomaterial-guided therapies [8-12], none can fully and stably reconstruct the entire joint surface [13-16], showing the need to develop novel avenues of research that can overcome the intrinsically poor ability of the cartilage for self-repair. In this regard, gene therapy offers strong tools to restore the impaired homeostasis in the damaged OA cartilage over extended periods of time by delivering stable gene sequences coding for factors capable of modulating the phenotype of the OA articular chondrocytes $[17,18]$. 
Particularly, gene transfer vehicles based on the small human adeno-associated virus (AAV) are currently the most suitable systems for translational human OA gene therapy $[17,18]$. Recombinant AAV (rAAV) vectors have a specific ability to highly, safely, and persistently transduce OA articular chondrocytes as stable, non-deleterious viral episomes in vitro and in situ when embedded in their dense extracellular matrix (ECM) (up to $80 \%$ efficiency for at least 150 days) and in experimental models of OA in vivo (at least 13 weeks) [19-26] compared with other, less effective, and/or detrimental classes of vectors (nonviral, adenoviral, retro-/lentiviral vectors) $[17,18]$. While a number of therapeutic genes have been previously reported for their ability to stimulate the reparative processes in OA chondrocytes or prevent OA-associated matrix degradation via rAAV (such as an interleukin-1 receptor antagonist (IL-1Ra) [27] or a short hairpin RNA against IL-1 beta (IL-1 $\beta$ ) [28], the insulin-like growth factor I (IGF-I) [29], sex-determining region Y-type high mobility group box 9 (SOX9) transcription factor [30], basic fibroblast growth factor (FGF-2) alone or combined with SOX9 [31], and transforming growth factor beta (TGF- $\beta$ ) alone [32,33] or with SOX9 [34]) none were capable of fully restoring the original chondrocyte phenotype of the cells, an observation supporting the concept of investigating novel, more effective therapeutic conditions. Interestingly, these earlier reports largely focused on targeting injured chondrocytes in two-dimensional culture systems or using non-physiological setups in biomaterials, while little is known on the feasibility of targeting them in a more natural, three-dimensional (3D) environment where they naturally embed themselves in their altered ECM.

Our goal was therefore to examine the benefits of modifying human OA articular chondrocytes in $3 \mathrm{D}$ aggregate cultures via rAAV-mediated sox 9 gene transfer relative to control conditions (reporter red fluorescent protein (RFP) or lacZ gene vectors, absence of vector treatment) in light of the superior effects of the SOX9 transcription factor on supporting the chondrocyte phenotype relative to other (growth) factors [35] due to its key, specific impact on cartilage formation [36]. The present results show that effective, safe sox 9 overexpression can be achieved in human OA chondrocytes when maintained in their ECM in 3D (aggregate) culture conditions over time (21 days), leading to the deposition of significantly higher levels of typical ECM compounds (proteoglycans, type-II collagen) and to a reduction of undesirable hypertrophic differentiation events (type- $X$ collagen) relative to control treatments. Overall, these findings support the concept of using rAAV as a powerful, direct gene transfer method to redirect human OA chondrocytes towards a native phenotype in a 3D, ECM-adapted environment as a tool to treat human $\mathrm{OA}$ in original conditions in translational regenerative medicine.

\section{Materials and Methods}

\subsection{Chemicals and Reagents}

All reagents were from Sigma (Munich, Germany) unless otherwise indicated. Recombinant TGF- $\beta 3$ was from R\&D Systems (Wiesbaden, Germany). The anti-SOX9 (C-20) antibody was from Santa Cruz Biotechnology (Heidelberg, Germany), the anti-type-II collagen (II-II6B3) antibody from the NIH Hybridoma Bank (University of Iowa, Ames, USA), and the anti-type-X collagen (COL-10) antibody from Sigma. Biotinylated secondary antibodies and the ABC kit were from Vector Laboratories (Grünberg, Germany). The $\beta$-gal Staining Kit and the Cell Proliferation Reagent WST-1 were from Roche Applied Science (Mannheim, Germany). The Beta-Glo ${ }^{\circledR}$ Assay System was from Promega (Mannheim, Germany). The type-II collagen ELISA (Human COL2A1) was purchased at Cusabio (College Park, MD, USA).

\subsection{Cell Culture}

Human normal articular cartilage was obtained from unaffected knee joints removed during tumor surgery $(n=4,21-43$ years of age). Osteoarthritis was excluded on safranin O-stained sections according to the Mankin scale (Mankin score 1-2) [37]. Human osteoarthritic cartilage was obtained from the joints of patients undergoing total knee arthroplasty $(n=4,69-81$ years of age) (Mankin score 7-9). The study was approved by the Ethics Committee of the Saarland Physicians Council 
(Ärztekammer des Saarlandes, Ethik-Kommission, No. 267/17). All patients provided informed consent to participate in the study before inclusion in the study. All procedures were in accordance with the Helsinki Declaration. Chondrocytes were processed according to standard protocols [38]. The resulting fraction was washed, pelleted, and resuspended in DMEM containing 10\% fetal bovine serum with $100 \mathrm{U} / \mathrm{mL}$ penicillin and $100 \mu \mathrm{L} / \mathrm{mL}$ streptomycin (growth medium). Cells were plated in T75 flasks and maintained at $37{ }^{\circ} \mathrm{C}$ in a humidified atmosphere with $5 \% \mathrm{CO}_{2}$. The medium was exchanged after $24 \mathrm{~h}$ and every $2-3$ days thereafter using growth medium. Cells (passage 1-2) were detached and replated for further experiments at the appropriate densities [39].

\subsection{Plasmids and $r A A V$ Vectors}

The constructs were derived from pSSV9, an AAV-2 genomic clone [40,41]. rAAV-lacZ carries the lac $Z$ gene for $E$. coli $\beta$-galactosidase ( $\beta$-gal) placed under the control of the cytomegalovirus immediate-early (CMV-IE) promoter [30,31,39,42,43]. rAAV-RFP carries the Discosoma sp. red fluorescent protein (RFP) gene and rAAV-FLAG-hsox9, a 1.7-kb FLAG-tagged human sox9 (hsox9) cDNA fragment $[30,31,39,43]$, both cloned in rAAV-lacZ in place of lacZ. The vectors were packaged as conventional (not self-complementary) vectors using a helper-free, two-plasmid transfection system in the 293 packaging cell line (an adenovirus-transformed human embryonic kidney cell line) with the packaging plasmid pXX2 and the Adenovirus helper plasmid pXX6 as previously described [43]. The vector preparations were purified by dialysis and titered by real-time PCR, averaging $10^{10}$ transgene copies/mL (viral particles to functional vectors $=500 / 1$ ) $[30,31,39,42,43]$.

\section{4. rAAV-Mediated Gene Transfer}

Aggregate cell cultures $\left(2 \times 10^{5}\right.$ cells/aggregate $)$ were prepared and kept in defined chondrogenic medium (high-glucose DMEM, $4.5 \mathrm{~g} / \mathrm{L}$ penicillin/streptomycin, $6.25 \mu \mathrm{g} / \mathrm{mL}$ insulin, $6.25 \mu \mathrm{g} / \mathrm{mL}$ transferrin, $6.25 \mu \mathrm{g} / \mathrm{mL}$ selenous acid, $5.35 \mu \mathrm{g} / \mathrm{mL}$ linoleic acid, $1.25 \mu \mathrm{g} / \mathrm{mL}$ bovine serum albumin, $1 \mathrm{mM}$ sodium pyruvate, $37.5 \mu \mathrm{g} / \mathrm{mL}$ ascorbate 2 -phosphate, $10^{-7} \mathrm{M}$ dexamethasone, $10 \mathrm{ng} / \mathrm{mL}$ TGF- $\beta 3$ ) at $37^{\circ} \mathrm{C}$ in a humidified atmosphere with $5 \% \mathrm{CO}_{2}$ [39,42]. The cells formed a free-floating mass within $24 \mathrm{~h}$ that was transduced as a single shot with $\mathrm{rAAV}\left(20\right.$ or $40 \mu \mathrm{L}$ vector, i.e., 4 or $8 \times 10^{5}$ functional recombinant viral particles and multiplicity of infection $(\mathrm{MOI})=2$ or 4 ) one day after aggregate formation (or left untreated) and kept in defined medium for up to 21 days [39,42].

\subsection{Detection of Transgene Expression}

RFP expression was examined on whole aggregates by live fluorescence with a fluorescent microscope using a $568 \mathrm{~nm}$ filter (Olympus CKX41) [42]. Then, lacZ expression was monitored on whole aggregates by X-Gal staining under light microscopy (Olympus BX45; Olympus, Hamburg, Germany) and using the Beta-Glo ${ }^{\circledR}$ Assay System [42]. SOX9 expression was assessed on histological aggregate sections by immunohistochemistry using a specific primary antibody, a biotinylated secondary antibody, and the ABC method with diaminobenzidine (DAB) as the chromogen [39]. To control for secondary immunoglobulins, samples were processed with omission of the primary antibody. Samples were examined directly by light microscopy (Olympus BX45).

\subsection{Biochemical Assays}

The cultures were harvested and digested with papain [39,42]. The DNA contents were determined with a fluorimetric assay using Hoechst 33258 [39,42]. The type-II collagen contents were monitored by ELISA $[39,42]$. Data were normalized to total cellular proteins using a protein assay (Pierce Thermo Scientific, Fisher Scientific, Schwerte, Germany). Cell proliferation was monitored using the Cell Proliferation Reagent WST-1, with optical density (OD) being proportional to the cell numbers [39,42]. All measurements were performed with a GENios spectrophotometer/fluorometer (Tecan, Crailsheim, Germany). 


\subsection{Histological, Immunocytochemical, and Immunohistochemical Analyses}

The cultures were harvested and fixed in $4 \%$ formalin, dehydrated in graded alcohols, embedded in paraffin, and sectioned $(3 \mu \mathrm{m})$. Sections were stained with hematoxylin and eosin (H\&E) (cellularity) and safranin O (matrix proteoglycans) [30,31,39,42]. Expression of type-II and type-X collagen was detected by immunohistochemistry using specific primary antibodies, biotinylated secondary antibodies, and the ABC method with DAB as the chromogen $[30,31,39,42]$. Samples were examined under light microscopy (Olympus BX45).

\subsection{Histomorphometry}

SOX9 and type-X collagen expression was monitored by estimating the percentage of positively stained cells to the total numbers of cells on immunohistochemical sections and the cell densities by estimating the cells $/ \mathrm{mm}^{2}$ on H\&E-stained histological sections [30,31,39,42]. Safranin O staining and type-II collagen immunostaining were scored for uniformity and intensity according to a modified Bern score grading system [44] as: 0 (no staining), 1 (heterogeneous and/or weak staining), 2 (homogeneous and/or moderate staining), 3 (homogeneous and/or intense staining), and 4 (very intense staining). All sections were scored blind by two individuals with regard to the conditions. All evaluations were performed using ten serial histological and immunohistochemical sections of aggregate cultures for each parameter, test, and replicate condition with the SIS analySIS program (Olympus), Adobe Photoshop (Adobe Systems, Unterschleissheim, Germany), Scion Image (Scion Corporation, Frederick, MD, USA), and ImageJ (NIH, Bethesda, Maryland, USA) [30,31,39,42].

\subsection{Real-Time RT-PCR Analysis}

Total cellular RNA was extracted from the cultures using the RNeasy Protect Mini Kit with an on-column RNase-free DNase treatment (Qiagen, Hilden, Germany). RNA was eluted in $30 \mu \mathrm{L}$ RNase-free water. Reverse transcription was carried out with $8 \mu \mathrm{L}$ eluate using the 1st Strand cDNA Synthesis kit for RT-PCR (AMV; Roche Applied Science) [39,42]. An aliquot of the cDNA product $(2 \mu \mathrm{L})$ was amplified with real-time PCR using the Brilliant SYBR Green QPCR Master Mix (Stratagene, Agilent Technologies, Waldbronn, Germany) on an Mx3000P QPCR operator system (Stratagene) as follows: Initial incubation $\left(95^{\circ} \mathrm{C}, 10 \mathrm{~min}\right.$ ), amplification for 55 cycles (denaturation at $95{ }^{\circ} \mathrm{C}, 30 \mathrm{~s}$; annealing at $55^{\circ} \mathrm{C}, 1 \mathrm{~min}$; extension at $\left.72{ }^{\circ} \mathrm{C}, 30 \mathrm{~s}\right)$, denaturation $\left(95^{\circ} \mathrm{C}, 1 \mathrm{~min}\right)$, and final incubation $\left(55^{\circ} \mathrm{C}, 30 \mathrm{~s}\right)[39,42]$. The primers (Invitrogen, Darmstadt, Germany) used were type-II collagen (COL2A1; chondrogenic maker) (forward, 5'-GGACTTTTCTCCCCTCTCT-3'; reverse, $5^{\prime}$-GACCCGAAGGTCTTACAGGA-3'), type-X collagen (COL10A1; marker of hypertrophy) (forward 5'-CCCTCTTGTTAGTGCCAACC-3'; reverse 5'-AGATTCCAGTCCTTGGGTCA-3'), and glyceraldehyde 3-phosphate dehydrogenase (GAPDH; housekeeping gene) (forward 5'-GAAGGTGAAGGTCGGAGTC-3'; reverse 5'-GAAGATGGTGATGGGATTTC-3') (all $150 \mathrm{nM}$ final concentration) $[39,42]$. Control conditions included reactions using water and nonreverse-transcribed mRNA. Specificity of the products was confirmed by melting curve analysis and agarose gel electrophoresis. The threshold cycle $(\mathrm{Ct})$ value for each gene of interest was measured for each amplified sample using MxPro QPCR software (Stratagene), and values were normalized to GAPDH expression by using the $2^{-\Delta \Delta C t}$ method [39,42].

\subsection{Statistical Analysis}

Experimental tests were performed in triplicate in three independent experiments. Data are expressed as mean \pm standard deviation (SD) of separate experiments. The $t$-test was employed where appropriate. $p$ values of less than 0.05 were considered statistically significant. 


\section{Results}

3.1. Sustained, Safe Dose-Dependent Overexpression of Reporter RFP and lacZ Transgenes via rAAV in 3D Aggregate Cultures of Human Normal and OA Articular Chondrocytes

The reporter $\mathrm{rAAV}-\mathrm{RFP}$ and $\mathrm{rAAV}-\mathrm{lac} Z$ vectors were first applied to 3D aggregate cultures of human normal and OA articular chondrocytes at various vector doses to monitor a possible dose-dependent, safe transgene expression in the cells in this particular three-dimensional (3D) environment over time (21 days).

An analysis by live fluorescence revealed a more intense, homogenous RFP signal both in human normal and OA aggregates transduced with rAAV-RFP at the higher vector dose (40 versus $20 \mu \mathrm{L}$ ), by day 2 after transduction and over the whole period of evaluation (21 days) (Figure 1). Detection of lacZ expression by X-Gal staining at the end of the evaluation period demonstrated a stronger, homogenous staining intensity at the higher vector dose (40 versus $20 \mu \mathrm{L}$ ), especially in human OA aggregates, while no staining was noted in the conditions where the rAAV-lacZ vector was omitted (Figure 2A). Such findings were corroborated by an estimation of the $\beta$-gal activities in the samples by Beta-Glo ${ }^{\circledR}$ Assay, with significant differences reached when applying rAAV-lacZ at 40 versus $20 \mu \mathrm{L}$ (normal aggregates: 1.8-fold difference, $p=0.017$; OA aggregates: 1.2-fold difference, $p=0.026$ ) or relative to the lack of vector treatment (normal aggregates: 14.3-fold difference, $p=0.002$; OA aggregates: 10.2-fold difference, $p \leq 0.001$ ) or when comparing gene transfer of $20 \mu \mathrm{L}$ rAAV-lacZ versus the "no vector" condition (normal aggregates: 8-fold difference, $p=0.006$; OA aggregates: 8.5-fold difference, $p=0.002$ ) (Figure 2B). Gene transfer with rAAV was safe, even at the higher (rAAV-lacZ) vector dose applied $(40 \mu \mathrm{L})$, as shown by the lack of detrimental effects of the vectors over time on the relative cell proliferation indices in treated (rAAV-lacZ) versus control aggregates (absence of vector condition) ( $p \geq 0.375)$ (Figure $2 \mathrm{C}$ ).
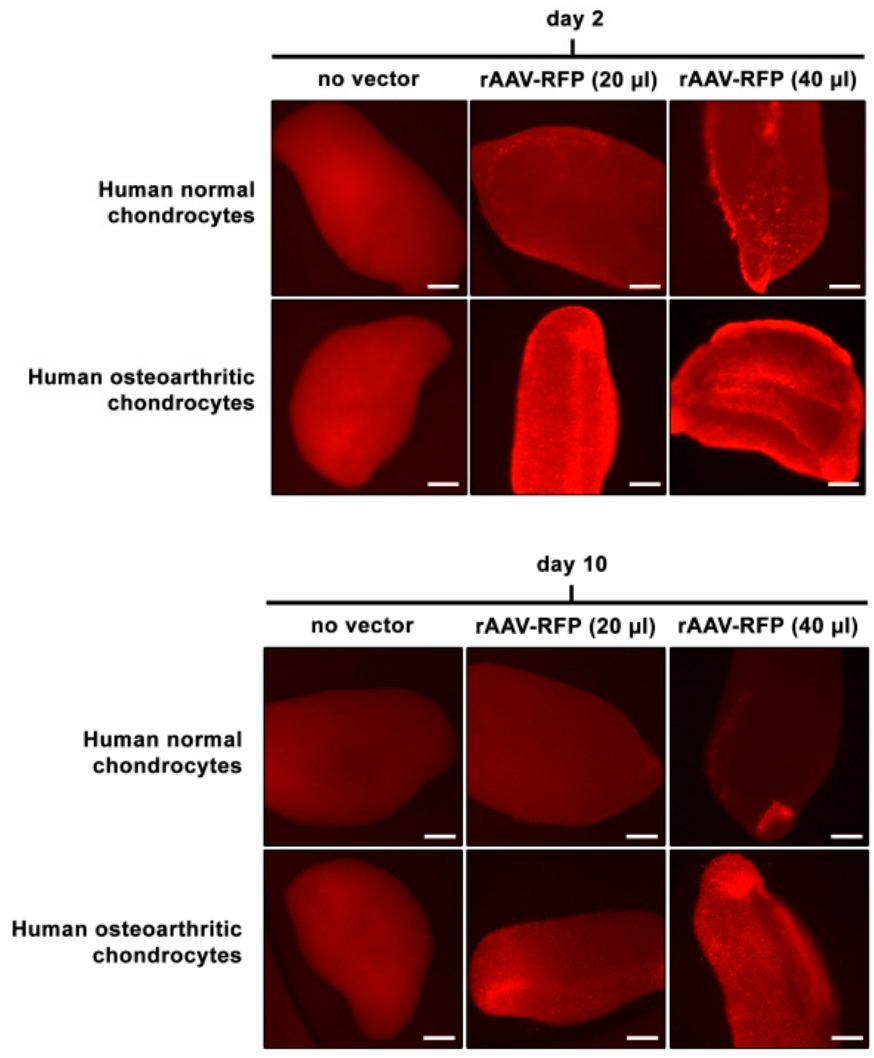

Figure 1. Cont. 


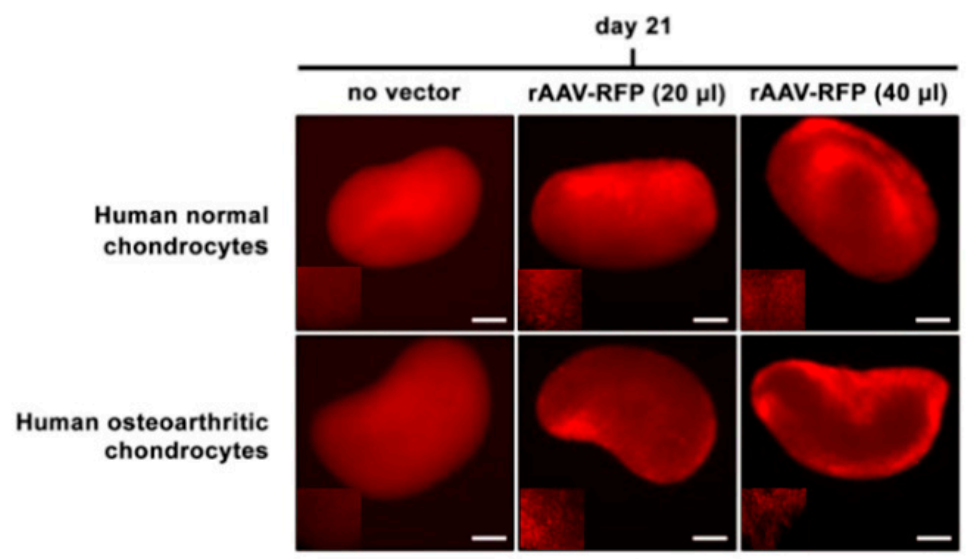

Figure 1. Over time transgene (red fluorescent protein, RFP) expression in recombinant adeno-associated viral (rAAV)-transduced aggregate cultures of human normal and osteoarthritis (OA) chondrocytes. Cell aggregates were transduced with rAAV-RFP $(20$ or $40 \mu \mathrm{L})$ versus lack of vector treatment as described in the Materials and Methods. RFP expression was monitored at the denoted time points by analysis of live fluorescence with regular light overlay (RFP expression can be visualized by fluorescent dots in individual cells in the insets of day 21 at magnification x20) as described in the Materials and Methods (all representative data). Scale bars: $50 \mu \mathrm{m}$.

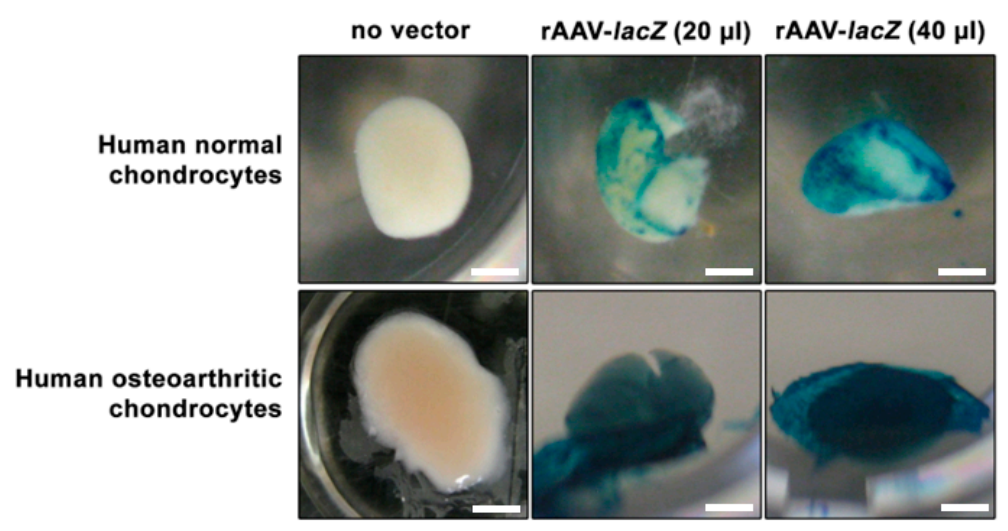

(A)

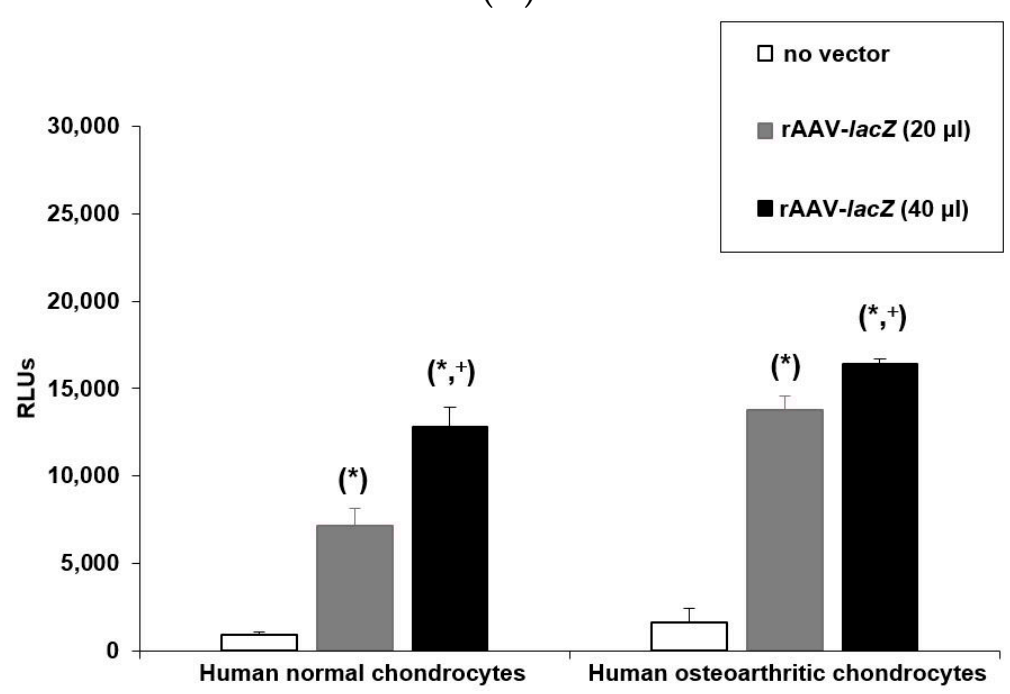

(B)

Figure 2. Cont. 


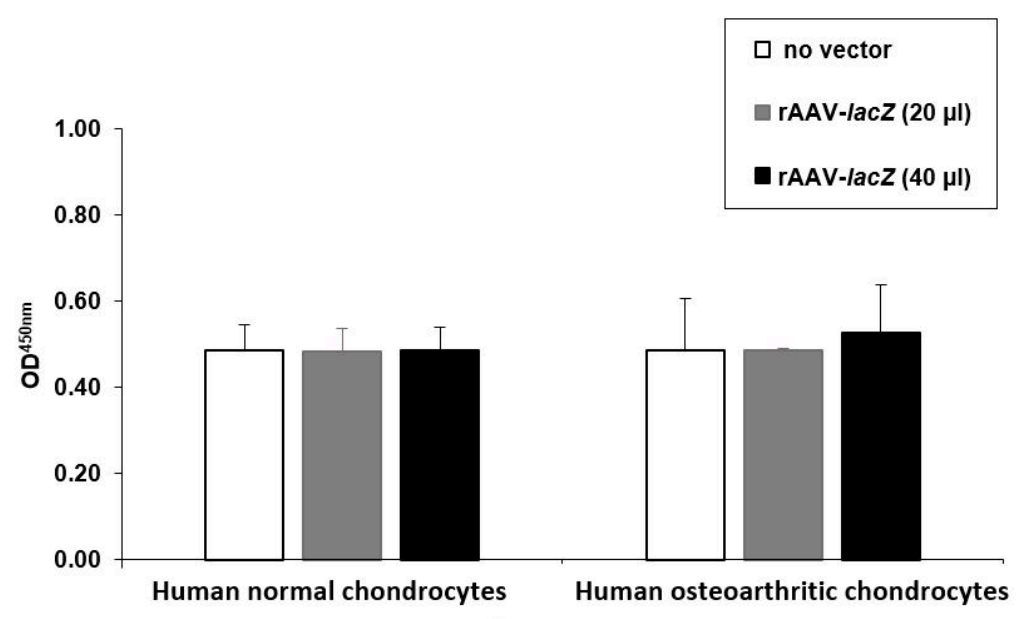

(C)

Figure 2. Safe transgene (lacZ) expression in rAAV-transduced aggregate cultures of human normal and OA chondrocytes. Cell aggregates were transduced with rAAV-lacZ ( 20 or $40 \mu \mathrm{L}$ ) versus lack of vector treatment as described in Figure 1 and in the Materials and Methods. lacZ expression (A, B) was monitored after 21 days by X-Gal staining (A); all representative data; scale bars: $1 \mathrm{~mm}$ ) and using the Beta-Glo ${ }^{\circledR}$ Assay System (B) as described in the Materials and Methods. The relative cell proliferation indices in treated (rAAV-lacZ) versus control aggregates (absence of vector condition) (C) were monitored after 21 days using the Cell Proliferation Reagent WST-1 as described in the Materials and Methods. Statistically significant compared with *no vector treatment and ${ }^{+} \mathrm{rAAV}-l a c Z$ $(20 \mu \mathrm{L})$.

3.2. Efficient, Prolonged $r A A V$-Mediated Therapeutic sox9 Overexpression in Aggregate Cultures of Human Normal and $O A$ Articular Chondrocytes

Aggregate cultures of human normal and OA articular chondrocytes were then transduced with the candidate rAAV-FLAG-hsox 9 at the higher, optimal, and safe vector dose $(40 \mu \mathrm{L})$ over time (21 days) in order to evidence the ability of this vector class to overexpress sox 9 in the cells in this $3 \mathrm{D}$ environment versus control (rAAV-lacZ, lack of vector) treatments.

An evaluation of SOX9 production by immunohistochemistry showed significantly higher, homogenous levels of sox9 expression upon rAAV-FLAG-hsox9 gene transfer in both types of cells relative to the control conditions (normal aggregates: 10.7-fold and 13.2-fold difference versus rAAV-lacZ and absence of vector treatment, respectively, $p \leq 0.001$; OA aggregates: 10.2-fold and 19.2-fold difference versus rAAV-lacZ and absence of vector treatment, respectively, $p \leq 0.001$ ) while no difference was noted between control conditions $(p \geq 0.074)$ (Figure 3 and Table 1$)$.

Table 1. Histomorphometric analyses in rAAV-transduced aggregate cultures of human normal and OA chondrocytes (day 21).

\begin{tabular}{ccccccc}
\hline \multirow{2}{*}{ Assay } & \multicolumn{2}{c}{ Human Normal Cell Aggregates } & \multicolumn{2}{c}{ Human OA Cell Aggregates } \\
\cline { 2 - 6 } & - & lacZ & sox9 & - & lacZ & sox9 \\
\hline SOX9 & $5.5(1.3)$ & $6.8(2.2)$ & $72.5(1.7)^{*,+}$ & $4.3(1.0)$ & $8.0(2.9)$ & $81.8(1.7)^{*,+}$ \\
Cell densities & $3,733(533)$ & $3,797(352)$ & $3,907(469)$ & $4,133(399)$ & $3,847(68)$ & $4,072(565)$ \\
Safranin O & $1.3(0.3)$ & $1.6(0.3)$ & $3.3(0.3)^{*,+}$ & $1.4(0.4)$ & $1.6(0.4)$ & $3.1(0.5)^{*,+}$ \\
Type-II collagen & $2.1(0.3)$ & $1.6(0.2)$ & $3.6(0.5)^{*,+}$ & $1.9(0.4)$ & $1.7(0.3)$ & $3.6(0.4)^{*,+}$ \\
Type-X collagen & $30.8(2.2)$ & $31.8(2.6)$ & $18.3(2.5)^{*,+}$ & $28.5(3.5)$ & $24.8(0.5)$ & $17.3(3.5)^{*,+}$ \\
\hline
\end{tabular}

Values are given as mean (SD). SOX9 and type-X collagen expression are in \% of positively stained cells to the total numbers of cells on immunohistochemical sections. The cell densities are in cells $/ \mathrm{mm}^{2}$. Safranin $\mathrm{O}$ staining and type-II collagen expression was scored for uniformity and intensity according to a modified Bern score grading system [44] as: 0 (no staining), 1 (heterogeneous and/or weak staining), 2 (homogeneous and/or moderate staining), 3 (homogeneous and/or intense staining), and 4 (very intense staining). Statistically significant compared with *no vector treatment and ${ }^{+} \mathrm{rAAV}-\mathrm{lacZ}$. 


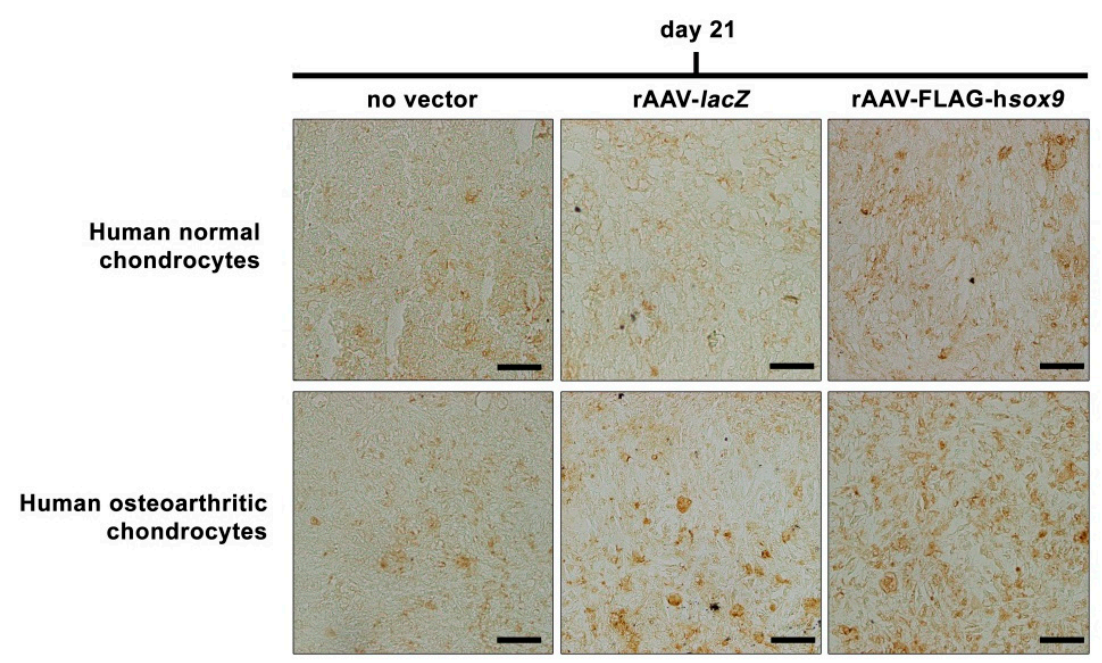

Figure 3. Transgene (SOX9) expression in rAAV-transduced aggregate cultures of human normal and OA chondrocytes. Cell aggregates were transduced with rAAV-FLAG-hsox9 versus rAAV-lacZ (40 $\mu \mathrm{L}$ each vector) or lack of vector treatment as described in Figures 1 and 2 and in the Materials and Methods. SOX9 expression was monitored after 21 days by immunohistochemistry as described in the Materials and Methods (magnification x40; all representative data of the central region of the aggregates). Scale bars: $20 \mu \mathrm{m}$.

3.3. Effects of sox9 Overexpression via rAAV upon the Metabolic Activities of Human Normal and $O A$ Articular Chondrocytes in Aggregate Cultures

Aggregate cultures of human normal and OA articular chondrocytes were next transduced as a single shot with the candidate rAAV-FLAG-hsox 9 at the higher, optimal vector dose over time (21 days) in order to determine a potential influence of the candidate treatment upon the proliferative and anabolic processes in the cells in this 3D environment versus control (rAAV-lacZ, lack of vector) treatments.

An evaluation of the cell densities in the aggregates revealed no significant difference between rAAV-FLAG-hsox 9 application and the control conditions in both types of cells ( $p \geq 0.171)$ (Figure 4 and Table 1), a finding substantiated by an analysis of the DNA contents in the aggregates $(p \geq 0.129)$ (Table 2). In marked contrast, administration of the rAAV-FLAG-hsox9 vector led to significantly increased levels of matrix proteoglycans in both types of cells on safranin O-stained, scored histological sections of aggregates versus control conditions $(p \leq 0.005)$ (Figure $5 \mathrm{~A}$ and Table 1$)$. Similar results were noted for type-II collagen expression, with significantly higher deposition of this major cartilage matrix compound seen on immunohistochemical sections from aggregates (Figure 5B) following rAAV-FLAG-hsox 9 gene transfer in both types of cells relative to control treatments $(p \leq 0.005)$ (Table 1). Accordingly, the type-II collagen contents in the aggregates were significantly higher upon rAAV-FLAG-hsox9 transduction (normal aggregates: 1.5-fold and 1.6-fold difference versus rAAV-lacZ and absence of vector treatment, respectively, $p \leq 0.005$; OA aggregates: 1.4-fold and 1.9-fold difference versus rAAV-lac $Z$ and absence of vector treatment, respectively, $p \leq 0.005$ ) (Table 2), a finding substantiated by a real-time RT-PCR analysis of type-II collagen expression (COL2A1) in the sox9-treated aggregates (normal aggregates: 2.6-fold and 2.7-fold difference versus rAAV-lac $Z$ and absence of vector treatment, respectively, $p \leq 0.001$; OA aggregates: 2.2-fold and 1.6-fold difference versus rAAV-lacZ and absence of vector treatment, respectively, $p \leq 0.013$ ) (Figure 6). 
Table 2. Biochemical analyses in rAAV-transduced aggregate cultures of human normal and OA chondrocytes (day 21).

\begin{tabular}{ccccccc}
\hline \multirow{2}{*}{ Assay } & \multicolumn{2}{c}{ Human Normal Cell Aggregates } & \multicolumn{2}{c}{ Human OA Cell Aggregates } \\
\cline { 2 - 6 } & \multicolumn{1}{c}{ lacZ } & sox9 & - & lacZ & sox9 \\
\hline DNA & $0.39(0.04)$ & $0.42(0.16)$ & $0.53(0.19)$ & $0.46(0.13)$ & $0.51(0.04)$ & $0.55(0.08)$ \\
Type-II collagen & $1.4(0.4)$ & $1.5(0.6)$ & $2.2(0.6)^{*++}$ & $1.2(0.4)$ & $1.7(0.6)$ & $2.3(0.8)^{*,+}$ \\
\hline
\end{tabular}

Values are given as mean (SD). The DNA contents are in $\mu \mathrm{g} / \mathrm{mg}$ total proteins and the type-II collagen contents in $\mathrm{ng} / \mathrm{mg}$ total proteins. Statistically significant compared with *no vector treatment and ${ }^{+} \mathrm{rAAV}-$ lacZ.

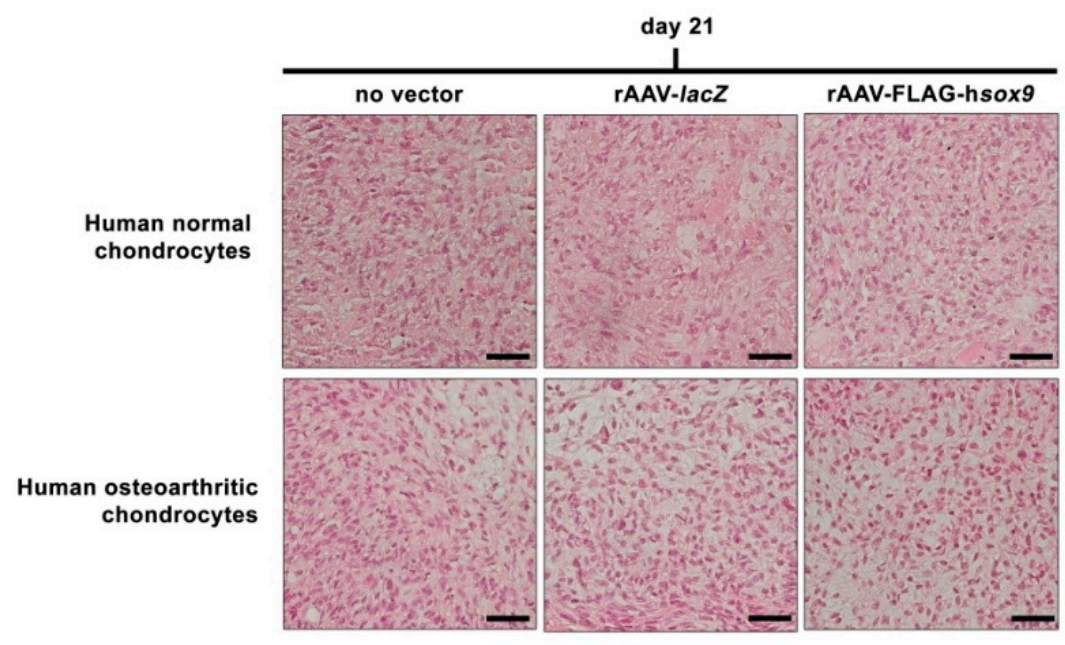

Figure 4. Cell proliferation in rAAV-transduced aggregate cultures of human normal and OA chondrocytes. Cell aggregates were transduced with rAAV-FLAG-hsox 9 versus rAAV-lacZ $(40 \mu \mathrm{L}$ each vector) or lack of vector treatment as described in Figures 1-3 and in the Materials and Methods. Cell proliferation was monitored after 21 days by H\&E staining as described in the Materials and Methods (magnification x40; all representative data). Scale bars: $20 \mu \mathrm{m}$.

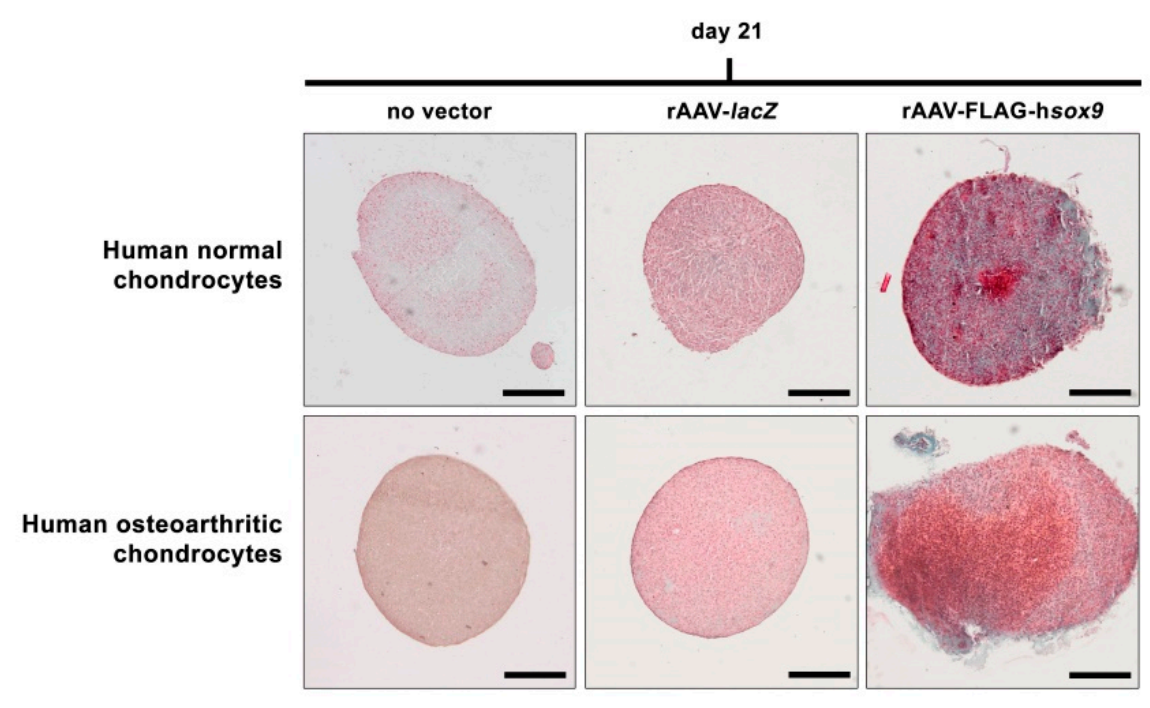

(A)

Figure 5. Cont. 


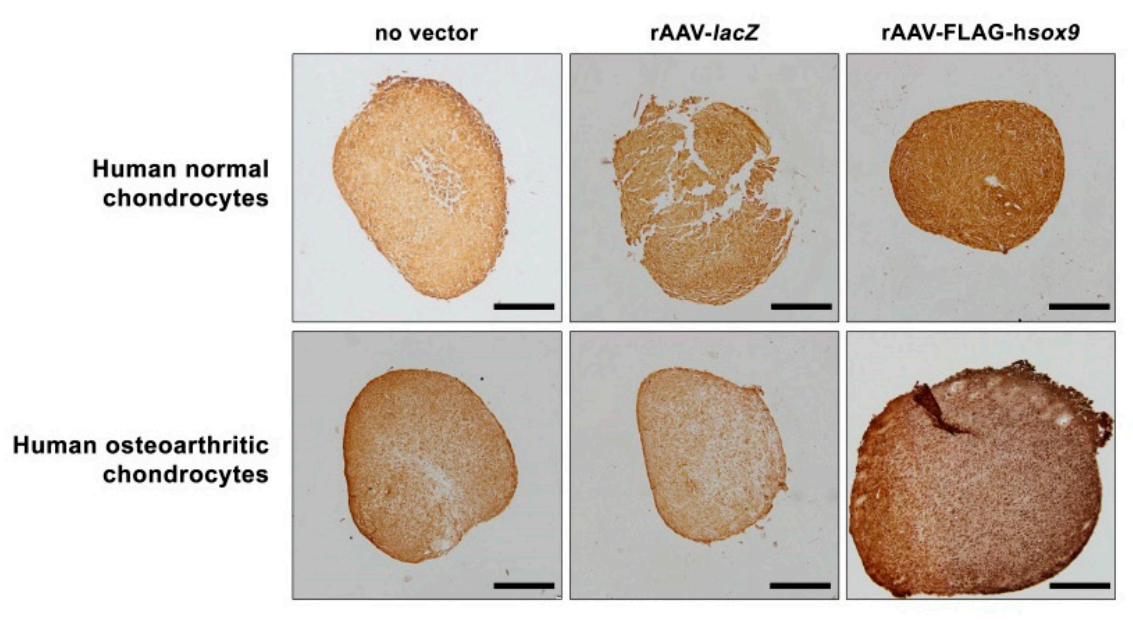

(B)

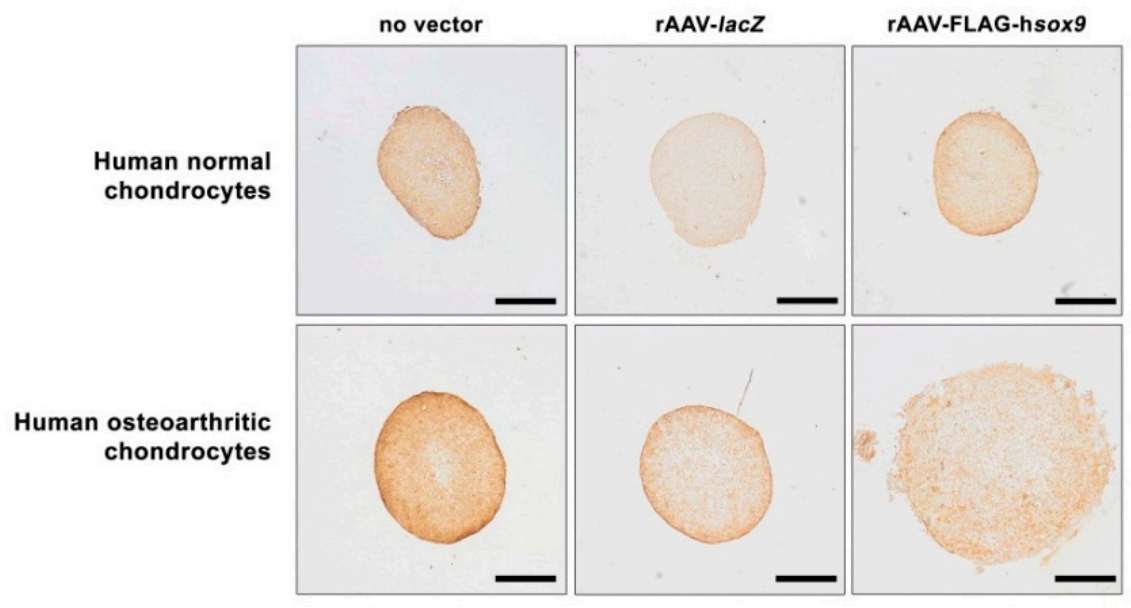

(C)

Figure 5. Extracellular matrix production in rAAV-transduced aggregate cultures of human normal and OA chondrocytes. Cell aggregates were transduced with rAAV-FLAG-hsox9 versus rAAV-lacZ (40 $\mu \mathrm{L}$ each vector) or lack of vector treatment as described in Figures 1-4 and in the Materials and Methods. Extracellular matrix production was assessed after 21 days (A) by safranin O staining and $(\mathbf{B}, \mathbf{C})$ by immunohistochemical detection of type-II collagen (B) and type-X collagen (C) as described in the Materials and Methods (magnification x10; all representative data). Scale bars: $100 \mu \mathrm{m}$.

\section{Human normal chondrocytes}

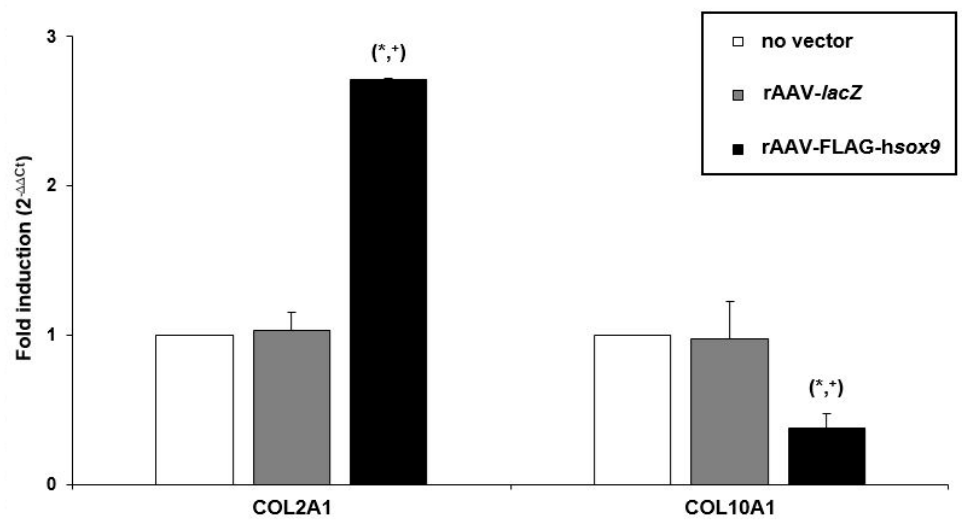

Figure 6. Cont. 


\section{Human osteoarthritic chondrocytes}

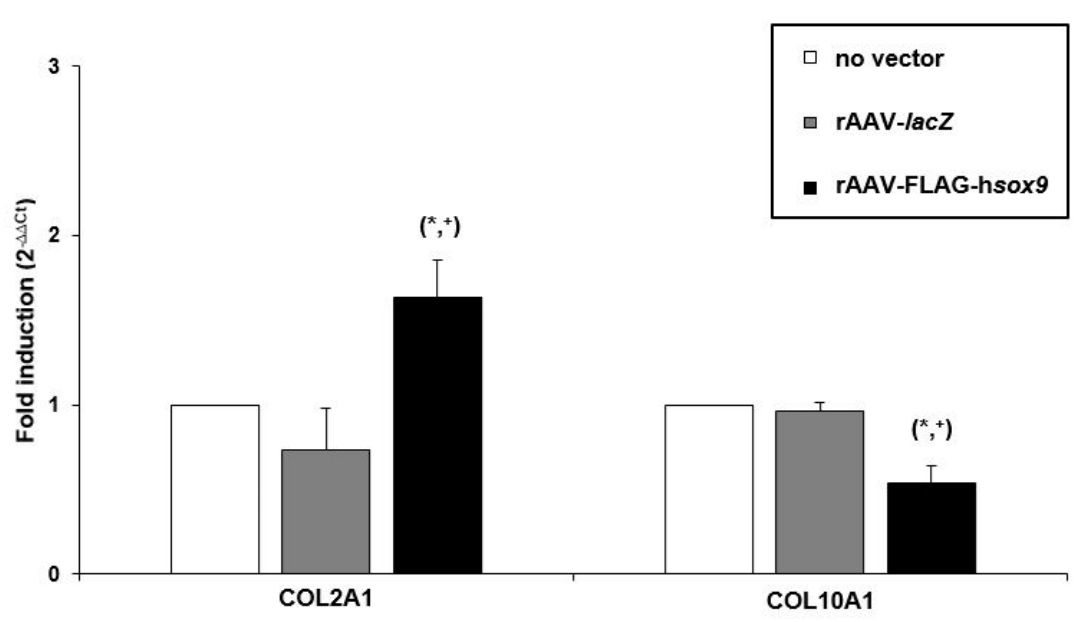

Figure 6. Real-time RT-PCR analysis in rAAV-transduced aggregate cultures of human normal and OA chondrocytes. Cell aggregates were transduced with rAAV-FLAG-hsox9 versus rAAV-lacZ $(40 \mu \mathrm{L}$ each vector) or lack of vector treatment as described in Figures 1-5 and in the Materials and Methods. After 21 days, mRNA was directly isolated from the aggregates and the gene expression profiles of type-II collagen (COL2A1) and type-X collagen (COL10A1) were monitored, with GAPDH serving as a housekeeping gene and internal control. Threshold cycle $(\mathrm{Ct})$ values were obtained for each target and for GAPDH as a control for normalization, and fold inductions (relative to the absence of vector treatment) were measured by using the $2^{-\Delta \Delta \mathrm{Ct}}$ method. Statistically significant compared with *no vector treatment and ${ }^{+}$rAAV-lacZ.

3.4. Effects of sox9 Overexpression via rAAV upon the Hypertrophic Activities of Human Normal and OA Articular Chondrocytes in Aggregate Cultures

Aggregate cultures of human normal and OA articular chondrocytes were finally modified by rAAV-FLAG-hsox 9 at the higher, optimal vector dose over time (21 days) to evidence a possible effect of sox 9 overexpression on hypertrophic events in the cells in this 3D environment relative to control (rAAV-lacZ, lack of vector) treatments.

Remarkably, application of the rAAV-FLAG-hsox 9 vector to aggregates led to significantly reduced levels of hypertrophic features in both types of cells as seen by less intense type- $X$ collagen deposition on immunohistochemical sections from aggregates versus control conditions (normal aggregates: 1.7-fold difference versus rAAV-lac $Z$ and absence of vector treatment, $p \leq 0.005$; OA aggregates: 1.4-fold and 1.6-fold difference versus rAAV-lac $Z$ and absence of vector treatment, respectively, $p \leq 0.005$ ) (Figure 5C and Table 1). This observation was corroborated by a real-time RT-PCR analysis of type-X collagen expression (COL10A1) in the sox9-treated aggregates (normal aggregates: 2.6-fold difference versus rAAV-lacZ and absence of vector treatment, $p \leq 0.004$; OA aggregates: 1.8-fold and 1.9-fold difference versus rAAV-lacZ and absence of vector treatment, respectively, $p \leq 0.017$ ) (Figure 6).

\section{Discussion}

Therapeutic gene transfer has several advantages to correct a progressive, irreversible disease like $\mathrm{OA}$ as it may afford durable treatments by long-term expression of healing genes being delivered, for example, via persistent $\mathrm{rAAV}$ vectors $[3,17,18,20]$. Among various candidates tested for experimental OA therapy, SOX9 emerged as one of the most potent agents to achieve this goal as this transcription factor has been reported for its impact on cartilage formation [36] and its superior chondroregenerative properties relative to other components (IGF-I, TGF- $\beta$ ) [35]. Interestingly, while rAAV-mediated gene transfer of sox9 has been attempted in OA chondrocytes in conditions where the cells were experimentally cultivated in a synthetic (material-based) environment [30], there is thus far no evidence showing the possible benefits of such an approach to modulate the OA phenotype of such cells in 
a naturally occurring 3D environment where they encase themselves in their own, specific ECM. The goal of this study was therefore to evaluate the potential of our rAAV-sox 9 construct to restore the altered homeostasis in primary human $\mathrm{OA}$ articular chondrocytes in 3D culture conditions (aggregate cultures) by activating the pro-anabolic responses of these cells over time and relative to control reporter (rAAV-lacZ) gene transfer and a condition without vector treatment.

The data first indicate that human OA chondrocytes are amenable to rAAV-mediated reporter (RFP, lacZ) gene transfer in the presence of their intrinsic, self-produced matrix elements in 3D [45,46] in a safe, dose-dependent manner over extended periods of time (21 days) versus untreated cells (up to 10.2-fold difference of $l a c Z$ expression as estimated by Beta-Glo ${ }^{\circledR}$ Assay), in good agreement with previous findings using this vector class $[19,20,32]$. Successful sox 9 overexpression was further noted in the rAAV-FLAG-hsox9-transduced OA chondrocytes in such a 3D environment relative to control conditions (reporter lac Z gene transfer, absence of vector application), with an up to 19.2-fold significant difference in SOX9 levels, again concordant with previous work in a synthetic, less physiological situation [30]. Overall, the levels of transgene expression achieved in 3D OA cell cultures were similar to those in their normal counterparts.

The results next revealed that overexpression of $\operatorname{sox} 9$ via rAAV was capable of activating the anabolic activities in human OA chondrocytes, with significantly higher levels of proteoglycan and type-II collagen deposition over time compared with the control conditions, all consistent with the properties of the transcription factor [47] and with our previous work using a synthetic culture setting [30]. Of note, and in agreement with previous observations [30,48], SOX9 had no significant effects on the viability and proliferation of the cells in such an environment. Importantly, administration of rAAV-FLAG-hsox 9 was capable of advantageously restraining undesirable hypertrophic (type-X collagen) expression in 3D cultures of human OA chondrocytes, again concordant with our previous work [30] and with the properties of SOX9 [48-50]. Here again, the effects observed in 3D OA cell cultures were similar to those in their normal counterparts, supporting the concept of applying the current rAAV-FLAG-hsox 9 vector for OA therapy when cells are in their specific ECM. Overall, these results are in line with and expand on the findings in synthetic (material-based) chondrocytes cell cultures with rAAV [30].

It remains to be seen whether the vector doses and MOI applied here will be adapted for translational approaches in vivo as Kyprioutou et al. [51] provided earlier evidence that too elevated SOX9 levels may impede type-II collagen deposition in chondrocytes in vitro by dysregulating the balance of transcription factors. Work is therefore currently ongoing to test the potential benefits of direct rAAV-FLAG-hso 9 delivery in relevant animal models of OA $[22,24,52]$ in conditions established here. If impairments of the homeostatic balance would occur as noted in vitro [49], the use of regulatable (tetracycline-sensitive) or cartilage-specific (type-II collagen, SOX9) control elements may be envisaged instead of the strong CMV-IE promoter/enhancer employed in the present work.

\section{Conclusions}

Overall, the present findings indicate that the candidate rAAV-FLAG-hsox 9 vector offers a safe and effective system to modulate the expression of essential versus unwanted matrix components in primary human OA articular chondrocytes in an altered 3D ECM environment. The ability of this therapeutic construct to promote such features makes sox9 gene transfer via rAAV a suited strategy for direct translational purposes to modulate the OA cellular phenotype in OA patients.

Author Contributions: O.D. carried out most of the experiments, analyzed, interpreted the data, and wrote the manuscript. J.F., J.K.V., and A.R.-R. participated in the experiments and in analyzing the data. G.S. participated in the experiments. M.C. was responsible for the conception and design of the experiments and for the writing and critical revisions of the manuscript. All authors read and approved the final manuscript.

Funding: This research was funded by the German Osteoarthritis Foundation (Deutsche Arthrose-Hilfe e.V.).

Acknowledgments: This research was funded by the German Osteoarthritis Foundation (Deutsche Arthrose-Hilfe e.V.). The authors thank R. J. Samulski (The Gene Therapy Center, University of North Carolina, Chapel Hill, NC), 
X. Xiao (The Gene Therapy Center, University of Pittsburgh, Pittsburgh, PA), and E. F. Terwilliger (Division of Experimental Medicine, Harvard Institutes of Medicine and Beth Israel Deaconess Medical Center, Boston, MA) for providing the genomic AAV-2 plasmid clones, the packaging plasmid pXX2, the Adenovirus helper plasmid pXX6, and the 293 cell line, and G. Scherer (Institute for Human Genetics and Anthropology, Albert-Ludwig University, Freiburg, Germany) for the human sox 9 cDNA.

Conflicts of Interest: The authors declare that they have no conflict of interest.

\section{References}

1. Loeser, R.F.; Goldring, S.R.; Scanzello, C.R.; Goldring, M.B. Osteoarthritis: A disease of the joint as an organ. Arthritis Rheum. 2012, 64, 1697-1707. [CrossRef] [PubMed]

2. Poole, A.R. Osteoarthritis as a whole joint disease. HSS J. 2012, 8, 4-6. [CrossRef] [PubMed]

3. Cucchiarini, M.; Girolamo, L.; Filardo, G.; Oliveira, J.M.; Orth, P.; Pape, D.; Reboul, P. Basic science of osteoarthritis. J. Exp. Orthop. 2016, 3, 22-39. [CrossRef] [PubMed]

4. Kapoor, M.; Martel-Pelletier, J.; Lajeunesse, D.; Pelletier, J.P.; Fahmi, H. Role of proinflammatory cytokines in the pathophysiology of osteoarthritis. Nat. Rev. Rheumatol. 2011, 7, 33-42. [CrossRef] [PubMed]

5. Goldring, M.B.; Otero, M. Inflammation in osteoarthritis. Curr. Opin. Rheumatol. 2011, 23, 471-478. [CrossRef] [PubMed]

6. Gomoll, A.H.; Filardo, G.; de Girolamo, L.; Espregueira-Mendes, J.; Marcacci, M.; Rodkey, W.G.; Steadman, J.R.; Zaffagnini, S.; Kon, E. Surgical treatment for early osteoarthritis. Part I: Cartilage repair procedures. Knee Surg. Sports Traumatol. Arthrosc. 2012, 20, 450-466. [CrossRef] [PubMed]

7. Filardo, G.; Kon, E.; Longo, U.G.; Madry, H.; Marchettini, P.; Marmotti, A.; Van Assche, D.; Zanon, G.; Peretti, G.M. Non-surgical treatments for the management of early osteoarthritis. Knee Surg. Sports Traumatol. Arthrosc. 2016, 24, 1775-1785. [CrossRef] [PubMed]

8. Bastos, R.; Mathias, M.; Andrade, R.; Bastos, R.; Balduino, A.; Schott, V.; Rodeo, S.; Espregueira-Mendes, J. Intra-articular injections of expanded mesenchymal stem cells with and without addition of platelet-rich plasma are safe and effective for knee osteoarthritis. Knee Surg. Sports Traumatol. Arthrosc. 2018, 26, 3342-3350. [CrossRef] [PubMed]

9. Delgado-Enciso, I.; Paz-Garcia, J.; Valtierra-Alvarez, J.; Preciado-Ramirez, J.; Almeida-Trinidad, R.; Guzman-Esquivel, J.; Mendoza-Hernandez, M.A.; Garcia-Vega, A.; Soriano-Hernandez, A.D.; Cortes-Bazan, J.L.; et al. A phase I-II controlled randomized trial using a promising novel cell-free formulation for articular cartilage regeneration as treatment of severe osteoarthritis of the knee. Eur. J. Med. Res. 2018, 23, 52. [CrossRef] [PubMed]

10. Lamo-Espinosa, J.M.; Mora, G.; Blanco, J.F.; Granero-Moltó, F.; Nuñez-Córdoba, J.M.; Sánchez-Echenique, C.; Bondía, J.M.; Aquerreta, J.D.; Andreu, E.J.; Ornilla, E.; et al. Intra-articular injection of two different doses of autologous bone marrow mesenchymal stem cells versus hyaluronic acid in the treatment of knee osteoarthritis: Multicenter randomized controlled clinical trial (phase I/II). J. Transl. Med. 2016, 14, 246. [CrossRef] [PubMed]

11. Pers, Y.-M.; Rackwitz, L.; Ferreira, R.; Pullig, O.; Delfour, C.; Barry, F.; Sensebé, L.; Casteilla, L.; Fleury, S.; Bourin, P.; et al. Adipose mesenchymal stromal cell-based therapy for severe osteoarthritis of the knee: A phase I dose-escalation trial. Stem Cells Transl. Med. 2016, 5, 847-856. [CrossRef] [PubMed]

12. Soler, R.; Orozco, L.; Munar, A.; Huguet, M.; López, R.; Vives, J.; Coll, R.; Codinach, M.; Garcia-Lopez, J. Final results of a phase I-II trial using ex vivo expanded autologous mesenchymal stromal cells for the treatment of osteoarthritis of the knee confirming safety and suggesting cartilage regeneration. Knee 2016, 23, 647-654. [CrossRef] [PubMed]

13. Cucchiarini, M.; Madry, H. Use of tissue engineering strategies to repair joint tissues in osteoarthritis: Viral gene transfer approaches. Curr. Rheumatol. Rep. 2014, 16, 449-457. [CrossRef] [PubMed]

14. Im, G.-I. Tissue engineering in osteoarthritis: Current status and prospect of mesenchymal stem cell therapy. BioDrugs 2018, 32, 183-192. [CrossRef] [PubMed]

15. Ha, C.-W.; Park, Y.-B.; Kim, S.H.; Lee, H.-J. Intra-articular mesenchymal stem cells in osteoarthritis of the knee: A systematic review of clinical outcomes and evidence of cartilage repair. Arthroscopy 2019, 35, 277-288.e2. [CrossRef] [PubMed] 
16. Kim, S.H.; Ha, C.-W.; Park, Y.-B.; Nam, E.; Lee, J.-E.; Lee, H.-J. Intra-articular injection of mesenchymal stem cells for clinical outcomes and cartilage repair in osteoarthritis of the knee: A meta-analysis of randomized controlled trials. Arch. Orthop. Trauma Surg. 2019, 139, 971-980. [CrossRef] [PubMed]

17. Evans, C.H.; Huard, J. Gene therapy approaches to regenerating the musculoskeletal system. Nat. Rev. Rheumatol. 2014, 11, 234-242. [CrossRef] [PubMed]

18. Madry, H.; Cucchiarini, M. Gene therapy for human osteoarthritis: Principles and clinical translation. Expert Opin. Biol. Ther. 2016, 16, 331-346. [CrossRef] [PubMed]

19. Arai, Y.; Kubo, T.; Fushiki, S.; Mazda, O.; Nakai, H.; Iwaki, Y.; Imanishi, J.; Hirasawa, Y. Gene delivery to human chondrocytes by an adeno associated virus vector. J. Rheumatol. 2000, 27, 979-982.

20. Madry, H.; Cucchiarini, M.; Terwilliger, E.F.; Trippel, S.B. Recombinant adeno-associated virus vectors efficiently and persistently transduce chondrocytes in normal and osteoarthritic human articular cartilage. Hum. Gene Ther. 2003, 14, 393-402. [CrossRef]

21. Santangelo, K.S.; Nuovo, G.J.; Bertone, A.L. In vivo reduction or blockade of interleukin-1 $\beta$ in primary osteoarthritis influences expression of mediators implicated in pathogenesis. Osteoarthr. Cartil. 2012, 20, 1610-1618. [CrossRef] [PubMed]

22. Lee, H.H.; O’Malley, M.J.; Friel, N.A.; Payne, K.A.; Qiao, C.; Xiao, X.; Chu, C.R. Persistence, localization, and external control of transgene expression after single injection of adeno-associated virus into injured joints. Hum. Gene Ther. 2013, 24, 457-466. [CrossRef] [PubMed]

23. Wang, G.; Evans, C.H.; Benson, J.M.; A Hutt, J.; Seagrave, J.; A Wilder, J.; Grieger, J.C.; Samulski, R.J.; Terse, P.S. Safety and biodistribution assessment of sc-rAAV2.5IL-1Ra administered via intra-articular injection in a mono-iodoacetate-induced osteoarthritis rat model. Mol. Ther. Methods Clin. Dev. 2016, 3, 15052. [CrossRef]

24. Levings, R.S.W.; Smith, A.D.A.D.; Broome, T.T.A.; Rice, B.L.B.L.; Gibbs, E.P.E.P.; Myara, D.A.; Hyddmark, E.V.; Nasri, E.; Zarezadeh, A.; Levings, P.P.P.P.; et al. Self-complementary adeno-associated virus-mediated interleukin-1 receptor antagonist gene delivery for the treatment of osteoarthritis: Test of efficacy in an equine model. Hum. Gene Ther. Clin. Dev. 2018, 29, 101-112. [CrossRef] [PubMed]

25. Ji, Q.; Xu, X.; Kang, L.; Xu, Y.; Xiao, J.; Goodman, S.B.; Zhu, X.; Li, W.; Liu, J.; Gao, X.; et al. Hematopoietic PBX-interacting protein mediates cartilage degeneration during the pathogenesis of osteoarthritis. Nat. Commun. 2019, 10, 313. [CrossRef] [PubMed]

26. Zhao, L.; Huang, J.; Fan, Y.; Li, J.; You, T.; He, S.; Xiao, G.; Chen, D. Exploration of CRISPR/Cas9-based gene editing as therapy for osteoarthritis. Ann. Rheum. Dis. 2019, 78, 676-682. [CrossRef] [PubMed]

27. Watson, R.S.; Broome, T.A.; Levings, P.P.; Rice, B.L.; Kay, J.D.; Smith, A.D.; Gouze, E.; Gouze, J.N.; Dacanay, E.A.; Hauswirth, W.W.; et al. scAAV-mediated gene transfer of interleukin-1-receptor antagonist to synovium and articular cartilage in large mammalian joints. Gene Ther. 2013, 20, 670-677. [PubMed]

28. Santangelo, K.S.; Bertone, A.L.; Santangeloyz, K.; Bertoneyz, A. Effective reduction of the interleukin-1 $\beta$ transcript in osteoarthritis-prone guinea pig chondrocytes via short hairpin RNA mediated RNA interference influences gene expression of mediators implicated in disease pathogenesis. Osteoarthr. Cartil. 2011, 19, 1449-1457. [CrossRef]

29. Weimer, A.; Madry, H.; Venkatesan, J.K.; Schmitt, G.; Frisch, J.; Wezel, A.; Jung, J.; Kohn, D.; Terwilliger, E.F.; Trippel, S.B.; et al. Benefits of recombinant adeno-associated virus (rAAV)-mediated insulin-like growth factor I (IGF-I) overexpression for the long-term reconstruction of human osteoarthritic cartilage by modulation of the IGF-I axis. Mol. Med. 2012, 18, 346-358.

30. Cucchiarini, M.; Thurn, T.; Weimer, A.; Kohn, D.; Terwilliger, E.F. Madry, Restoration of the extracellular matrix in human osteoarthritic articular cartilage by overexpression of the transcription factor SOX9. Arthritis Rheum. 2007, 56, 158-167. [CrossRef]

31. Cucchiarini, M.; Terwilliger, E.F.; Kohn, D.; Madry, H. Remodelling of human osteoarthritic cartilage by FGF-2, alone or combined with Sox9 via rAAV gene transfer. J. Cell Mol. Med. 2009, 13, 2476-2488. [PubMed]

32. Ulrich-Vinther, M.; Stengaard, C.; Schwarz, E.M.; Goldring, M.B.; Soballe, K. Adeno-associated vector mediated gene transfer of transforming growth factor-beta1 to normal and osteoarthritic human chondrocytes stimulates cartilage anabolism. Eur. Cell. Mater. 2005, 10, 40-50. [CrossRef] [PubMed]

33. Venkatesan, J.K.; Rey-Rico, A.; Schmitt, G.; Wezel, A.; Madry, H.; Cucchiarini, M. rAAV-mediated overexpression of TGF- $\beta$ stably restructures human osteoarthritic articular cartilage in situ. J. Transl. Med. 2013, 11, 211. [CrossRef] [PubMed] 
34. Tao, K.; Frisch, J.; Venkatesan, J.K.; Schmitt, G.; Madry, H.; Lin, J.; Cucchiarini, M.; Rey-Rico, A. rAAV-mediated combined gene transfer and overexpression of TGF- $\beta$ and SOX9 remodels human osteoarthritic articular cartilage. J. Orthop. Res. 2016, 34, 2181-2190. [CrossRef] [PubMed]

35. Frisch, J.; Rey-Rico, A.; Venkatesan, J.K.; Schmitt, G.; Madry, H.; Cucchiarini, M. rAAV-mediated overexpression of sox 9 , TGF- $\beta$ and IGF-I in minipig bone marrow aspirates to enhance the chondrogenic processes for cartilage repair. Gene Ther. 2016, 23, 247-255. [CrossRef] [PubMed]

36. Bi, W.; Deng, J.M.; Zhang, Z.; Behringer, R.R.; De Crombrugghe, B. Sox9 is required for cartilage formation. Nat. Genet. 1999, 22, 85-89. [CrossRef] [PubMed]

37. Mankin, H.J.; Dorfman, H.; Lippiello, L.; Zarins, A. Biochemical and metabolic abnormalities in articular cartilage from osteo-arthritic human hips. J. Bone Jt. Surg. Am. 1971, 53, 523-537. [CrossRef]

38. Madry, H.; Trippel, S.B. Efficient lipid-mediated gene transfer to articular chondrocytes. Gene Ther. 2000, 7, 286-291. [CrossRef]

39. Venkatesan, J.K.; Ekici, M.; Madry, H.; Schmitt, G.; Kohn, D.; Cucchiarini, M. SOX9 gene transfer via safe, stable, replication-defective recombinant adeno-associated virus vectors as a novel, powerful tool to enhance the chondrogenic potential of human mesenchymal stem cells. Stem Cell. Res. Ther. 2012, 3, 22. [CrossRef]

40. Samulski, R.J.; Chang, L.S.; Shenk, T. A recombinant plasmid from which an infectious adeno-associated virus genome can be excised in vitro and its use to study viral replication. J. Virol. 1987, 61, 3096-3101.

41. Samulski, R.J.; Chang, L.S.; Shenk, T. Helper-free stocks of recombinant adeno-associated viruses: Normal integration does not require viral gene expression. J. Virol. 1989, 63, 3822-3828. [PubMed]

42. Cucchiarini, M.; Ekici, M.; Schetting, S.; Kohn, D.; Madry, H. Metabolic activities and chondrogenic differentiation of human mesenchymal stem cells following recombinant adeno-associated virus-mediated gene transfer and overexpression of fibroblast frowth factor 2. Tissue Eng. Part A 2011, 17, 1921-1933. [CrossRef] [PubMed]

43. Rey-Rico, A.; Frisch, J.; Venkatesan, J.K.; Schmitt, G.; Madry, H.; Cucchiarini, M. Determination of effective rAAV-mediated gene transfer conditions to support chondrogenic differentiation processes in human primary bone marrow aspirates. Gene Ther. 2015, 22, 50-57. [CrossRef] [PubMed]

44. Rey-Rico, A.; Venkatesan, J.K.; Sohier, J.; Moroni, L.; Cucchiarini, M.; Madry, H. Adapted chondrogenic differentiation of human mesenchymal stem cells via controlled release of TGF- $\beta 1$ from poly(ethylene oxide)-terephtalate/poly(butylene terepthalate) multiblock scaffolds. J. Biomed. Mater. Res. A 2015, 103, 371-383. [PubMed]

45. Battistelli, M.; Borzì, R.M.; Olivotto, E.; Vitellozzi, R.; Burattini, S.; Facchini, A.; Falcieri, E. Cell and matrix morpho-functional analysis in chondrocyte micromasses. Microsc. Res. Tech. 2005, 67, 286-295. [CrossRef] [PubMed]

46. Derfoul, A.; Miyoshi, A.; Freeman, D.; Tuan, R. Glucosamine promotes chondrogenic phenotype in both chondrocytes and mesenchymal stem cells and inhibits MMP-13 expression and matrix degradation. Osteoarthr. Cartil. 2007, 15, 646-655. [CrossRef] [PubMed]

47. Lefebvre, V.; Huang, W.; Harley, V.R.; Goodfellow, P.N.; De Crombrugghe, B. SOX9 is a potent activator of the chondrocyte-specific enhancer of the pro alpha1(II) collagen gene. Mol. Cell. Boil. 1997, 17, 2336-2346. [CrossRef]

48. Akiyama, H.; Lyons, J.P.; Mori-Akiyama, Y.; Yang, X.; Zhang, R.; Zhang, Z.; Deng, J.M.; Taketo, M.M.; Nakamura, T.; Behringer, R.R.; et al. Interactions between Sox9 and $\beta$-catenin control chondrocyte differentiation. Genome Res. 2004, 18, 1072-1087. [CrossRef]

49. Akiyama, H.; Chaboissier, M.-C.; Martin, J.F.; Schedl, A.; De Crombrugghe, B. The transcription factor Sox9 has essential roles in successive steps of the chondrocyte differentiation pathway and is required for expression of Sox5 and Sox6. Genome Res. 2002, 16, 2813-2828. [CrossRef]

50. Goldring, M.B.; Tsuchimochi, K.; Ijiri, K. The control of chondrogenesis. J. Cell. Biochem. 2006, 97, 33-44. [CrossRef]

51. Kyprioutou, M.; Fossard-Demoor, M.; Chadjichristos, C.; Ghayor, C.; de Crombrugghe, B.; Pujol, J.P.; Galéra, P. SOX9 exerts a bifunctional effect on type II collagen (COL2A1) expression in chondrocytes depending on the differentiation state. DNA Cell Biol. 2003, 22, 119-129. [CrossRef] [PubMed]

52. Cucchiarini, M.; Madry, H.; Terwilliger, E.F. Enhanced expression of the central survival of motor neuron (SMN) protein during the pathogenesis of osteoarthritis. J. Cell. Mol. Med. 2014, 18, 115-124. [CrossRef] [PubMed]

(C) 2019 by the authors. Licensee MDPI, Basel, Switzerland. This article is an open access article distributed under the terms and conditions of the Creative Commons Attribution (CC BY) license (http://creativecommons.org/licenses/by/4.0/). 